Syntax Literate : Jurnal Ilmiah Indonesia p-ISSN: 2541-0849

e-ISSN : 2548-1398

Vol. 6, No. 2, Februari 2021

\title{
HARGA DIRI POSITIF PADA IBU RUMAH TANGGA YANG MENOPAUSE BERUSIA 49 TAHUN KEATAS DI SIDOARJO JAWA TIMUR
}

\author{
Iffah Dewi Amalya, Andik Matulessy dan Amanda Pasca Rini \\ Universitas 17 Agustus 1945 (UNTAG) Surabaya Jawa Barat, Indonesia \\ Email: dewiiffah@yahoo.co.id, andikmatulessy@untag-sby.ac.id dan \\ amanda@untagsby.ac.id
}

\section{Abstract}

Change is one of the key words in the journey of human life. One of the life changing stages that is sure to help every woman who comes menopause. The purpose of this study is to describe positive self-esteem in subjects who have entered menopause as well as to explore, discover, and describe the subject of the factors that influence menopause. The research method used in this research is research conducted with case studies that are intrinsic in nature. The subjects of this study were women who had entered menopause. The number of subjects in this study is one person. The results showed that the subject had positive self-esteem, even though the subject was menopausal. The conclusion in this study that the subject respects others and does not underestimate others, respects himself and does not lower himself, expresses views or comments, especially when asked and rationalizes when he fails to do something, has many friends and also participates in socialization activities with the surrounding area. although not very active, but more likely to be active in adjusting to situations and environmental pressures, accepting the situation at menopause and feeling happy, accepting themselves well and being more confident about themselves who have entered menopause, accepting and appreciating criticism and suggestions from other people towards themselves, respecting themselves and proud of themselves, tend to not conform and accept conditions in physical and material terms, attitudes are not easily offended and can accept other people's attitudes well, there is a reaction from him having a way to overcome ya de ngan share stories with the closest people and always be grateful for what you have.

Keywords: self-esteem; women; menopause

\begin{abstract}
Abstrak
Perubahan adalah salah satu kata kunci dari perjalanan hidup manusia. Salah satu tahap perubahan kehidupan yang pasti dialami oleh setiap wanita adalah datangnya menopause. Tujuan dalam penelitian ini adalah untuk menggambarkan harga diri yang positif pada subjek yang sudah memasuki masa menopause serta untuk mendalami, menemukan, dan menggambarkan subjek dari faktor-faktor yang mempengaruhi menopause. Metode penelitian yang digunakan dalam penelitian ini adalah penelitian ini dilakukan dengan studi kasus yang bersifat intrinsik. Subjek penelitian ini adalah wanita yang sudah memasuki masa menopause. Jumlah subjek dalam penelitian ini adalah satu orang. Hasil penelitian menunjukkan bahwa subjek memiliki harga diri yang positif, walaupun subjek sudah menopause. Kesimpulan
\end{abstract}


pada penelitian ini subjek menghargai orang lain dan tidak merendahkan orang lain, menghargai diri sendiri dan tidak merendahkan diri sendiri, mengemukakan pandangan atau pendapat terutama ketika ditanya dan melakukan rasionalisasi ketika gagal melakukan sesuatu, memiliki banyak teman dan juga mengikuti kegiatan sosialisasi dengan daerah lingkungan sekitar, meskipun tidak terlalu aktif, tetapi lebih cenderung aktif dalam menyesuaikan diri dengan tuntutan dan tekanan lingkungan, menerima keadaan saat menopause dan merasa bahagia, menerima diri dengan baik dan lebih percaya diri terhadap dirinya yang sudah memasuki masa menopause, menerima dan menghargai kritik dan saran dari orang lain terhadap dirinya, menghormati diri sendiridan bangga terhadap diri sendiri, cenderung tidak konformitas dan menerima keadaan dalam hal fisik dan materi, sikap tidak mudah tersinggung dan dapat menerima sikap orang lain dengan baik, apabila terjadi kecemasan beliau memiliki cara untuk mengatasinya dengan berbagi cerita dengan orang-orang terdekat dan selalu mensyukuri apa yang dimiliki.

Kata kunci: harga diri; wanita; menopause

\section{Coresponden Author}

Email: dewiiffah@yahoo.co.id Artikel dengan akses terbuka dibawah lisensi

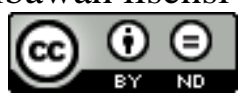

\section{Pendahuluan}

Salah satu tahap perubahan kehidupan yang pasti dialami oleh setiap wanita adalah datangnya menopause. Menopause merupakan tanda berakhirnya siklus menstruasi yang terjadi 12 bulan setelah periode terakhir menstruasi (Ermawati, 2018). Menopause merupakan keadaan biologis yang wajar yang ditandai dengan berhentinya menstruasi. Menopause mempengaruhi kualitas hidup melalui efeknya pada hormon, suasana hati, dan kondisi fisik secara keseluruhan (Olchowska-Kotala, 2018).

Transisi menopause adalah proses psikofisiologis yang kompleks (Drobnjak, Atsiz, Ditzen, Tuschen-Caffier, \& Ehlert, 2014) dan sering dikaitkan dengan gejala (hot flushes, keringat malam, disfungsi seksual, dll.), serta dengan perubahan fisik dan psikologis yang signifikan (Séjourné, Got, Solans, \& Raynal, 2019). Transisi menopause telah dikaitkan dengan sejumlah gangguan kesehatan mental dengan penurunan harga diri diidentifikasi sebagai salah satu konsekuensi psikologis negatif yang paling umum dari menopause (Elavsky \& McAuley, 2007).

Masa menopause yang terjadi pada wanita adalah hal alamiah. Ibarat tumbuhtumbuhan yang semula kecil, semakin membesar, sehingga menjadi sebuah pohon yang kokoh, kemudian pohon itu berbuah secara teratur mengikuti musimnya. Setelah usia sang pohon menjadi suatu titik tua, maka buahnya pun tidak muncul lagi, atau tidak mampu berproduksi lagi. Seperti pohon menjadi rapuh dan akhirnya tumbang untuk digantikan tanaman muda berikutnya sehingga menjadi generasi penerus. Begitulah, peristiwa alamiah yang dialami pohon, juga dialami oleh seorang wanita dalam perjalanan hidupnya. Titik ketuaan pada pohon sehingga tidak mampu berproduksi lagi, pada wanita dinamakan menopause, yaitu mulai usia antara 40 sampai 50 tahun 
(Kartono, 1992). Wanita menopause yang sangat sensitif terhadap efek dari fluktuasi hormonal (Orizani, 2014). Pada wanita menopause muncul kekhawatiran menjadi tua dan berkurang daya tariknya (Runiari, Hartati, \& Surinati, 2015).

Faktor yang mempengaruhi menopause, yaitu umur waktu mendapat haid pertama kali (menarch), kondisi kejiwaan dan pekerjaan, jumlah anak, penggunaan obat-obat keluarga berencana (KB), merokok, cuaca dan ketinggian tempat tinggal dari permukaan laut, sosio-ekonomi, menopause yang terlalu dini dan menopause yang terlambat (Blackburn, Davidson \& Kendell, 1994).

Berdasarkan uraian tersebut diperoleh kesimpulan bahwa wanita yang telah mengalami menopause digambarkan banyak mengalami masalah antara lain merasakan pergeseran dan perubahan-perubahan fisik dan psikis yang mengakibatkan timbulnya satu krisis dan simptom-simptom psikologis yang akan mempengaruhi harga diri pada wanita yang telah memasuki masa menopause. Harga diri diartikan sebagai evaluasi diri yang dibuat oleh setiap individu. Lebih spesifiknya adalah sikap seseorang terhadap dirinya sendiri dalam rentang dimensi positif-negatif (Abadiah, 2016).

Menopause merupakan periode menstruasi terakhir yang terjadi ketika hormonhormon yang mengontrol siklus menstruasi berada dalam kadar yang sangat rendah sehingga menstruasi tidak mungkin terjadi lagi (Subagya, Artanty, \& Hapsari, 2018). Menopause mengalami perubahan dalam masalah kesehatan seperti cepat lelah, pusing, berkeringat. Untuk mencegah penurunan kondisi tubuh biasanya mengkonsumsi vitamin, sayuran, buah-buahan, istirahat yang cukup, serta berolahraga. Dari penelitian ini akan diambil subjek yang walaupun telah mengalami menopause namun memiliki harga diri yang positif. Hal ini terlihat dari kegiatan subjek yang rutin tidak hanya menutup diri karena sudah mengalami menopause. Selain itu banyaknya dukungan yang diberikan keluarga maupun teman-teman subjek. Subjek selalu memandang positif pada setiap kejadian yang dialami serta subjek juga mengalami harga diri yang positif. Tujuan dalam penelitian ini adalah untuk menggambarkan harga diri yang positif pada subjek yang sudah memasuki masa menopause dan untuk mendalami, menemukan, dan menggambarkan subjek dari faktor-faktor yang mempengaruhi menopause.

\section{Metode Penelitian}

Metode penelitian yang digunakan dalam penelitian ini adalah penelitian ini dilakukan dengan studi kasus yang bersifat intrinsik, yaitu kasus yang diambil merupakan kasus yang menarik untuk diteliti. Menurut (Hidup, 2005) studi kasus merupakan metode untuk menghimpun dan menganalisis data berkenaan dengan studi kasus. Sesuatu dijadikan studi kasus biasanya karena ada masalah, kesulitan, hambatan, penyimpangan, tetapi bisa juga sesuatu dijadikan kasus meskipun tidak ada masalah, melainkan karena keunggulan atau keberhasilannya. Tujuan dari studi kasus adalah untuk memberikan gambaran secara mendetail tentang latar belakang, sifat-sifat serta karakter yang khas dari kasus, ataupun status dari individu, yang kemudian dari sifatsifat khas tersebut akan dijadikan suatu hal yang bersifat umum. 
Subjek penelitian ini adalah wanita yang sudah memasuki masa menopause. Jumlah subjek dalam penelitian ini adalah satu orang. Subjek yang merupakan seorang ibu rumah tangga yang sudah memasuki masa menopause sebagai key informan (kunci informasi). Subjek akan di wawancara dengan beberapa pertanyaan yang telah disiapkan. Kriteria wanita sebagai subjek penelitian adalah seorang ibu rumah tangga yang berusia 49 tahun, yang menopause serta subjek juga memiliki harga diri yang positif. Oleh karena itu penelitian ini akan menarik untuk dipublikasikan kepada seluruh wanita yang menopause dan bersedia untuk di wawancara. Guna mengecek kebenaran hasil wawancara subjek, dan menambah dengan observasi. Teknik pengumpulan data yang akan digunakan dalam penelitian ini adalah wawancara dan observasi.

\section{Hasil dan Pembahasan}

Berdasarkan hasil wawancara yang mengacu pada ciri dari (Gibson \& Jefferson, 2006) dan (Bernard, 1990) ditemukan beberapa temuan lapangan yang dapat digambarkan berikut ini, dan temuan tersebut di masukkan ke dalam tema-tema yang akan didiskripsikan berikut ini.

Mengawali hasil temuan penelitian, ditemukan bahwa kasus yang dihadapi subjek atas harga diri subjek saat memasuki masa menopause. Sebagaimana hasil petikan wawancara berikut ini;

Petikan hasil wawancara pada subjek adalah sebagaimana berikut ini;

Tidak mbak, buat apa juga saya merendahkan orang lain. Saya bisa nerima orang lain dengan bagaimana dia, karena kan memang sifat pribadi orang itu beda-beda mbak. (Wcr2H37) Tidak terlalu, saya biasa saja. Tergantung tempat dan situasinya seperti apa dulu ya mbak, ya pokoknya sederhana lah mbak. (Wcr9H38) Rendah diri itu kan sifat baik ya mbak, tapi kalau merendahkan diri sendiri itu kan merasa saya ini rendahan seperti itu, ya tidak mbak. (Wcr14H37) Saya perna mengutarakan pendapat saya, lebih tepatnya ke suami saya, saat suami saya membutuhkan pendapat saya. Suami saya juga sering untuk menanyakan sesuatu/meminta pendapat saya. Saya kan mungkin lebih tua dari suami saya, mungkin hanya berjarak beberapa bulan saja. Tetapi suami saya itu senang mendengarkan pendapat saya atau lebih sering untuk menanyai soal sesuatu. (Wcr21H37) Saat dia membeli baju atau celana untuk bekerja, bagaimana menyelesaikan ini, itu, ya banyak mbak.(Wcr33H37) Allah itu kan tidak pernah menguji hambanya melebihi batas kemampuan umatnya kan mbak, jadi saya percaya itu bahwa semua masalah pasti dapat diselesaikan. Lagian Alhamdulillah, sampai detik ini saya masih percaya itu \& saya selalu berdoa yang terbaik untuk semuanya. Tetapi selain itu juga saya mencari cara bagaimana saya menyelesaikannya. (Wcr39H38) Tidak mbak, saya memiliki banyak teman, saya juga mengikuti arisan rutin sebulan 1 kali. (Wcr53H38) Tidak mbak, saya menyikapinya ya biasa saja.Saya dibilang pasif ya tidak dibilang aktif juga tidak.Saya orangnya netral-netral saja mbak.Tetapi saya memiliki banyak teman. Bagi saya itu cukup. Selain itu saya juga memiliki keluarga yang anak dan suami saya selalu mendukung saya \& mendapatkan support yang baik dari 
semuanya. (Wcr60H38) Tidak, justru saya lebih dicintai oleh keluarga saya. Saya jadi bisa menerimanya dengan baik. Selain itu saya juga malah lebih dekat dengan suami saya. (Wcr73H38) Tidak mbak. (Wcr80H38) Tergantung ya mbak, kritik dan saran orang lain itu seperti apa. Kalau kritik dan saran itu menurut saya baik, saya mengambilnya. Tapi kalau tidak ya buat apa saya patuhi, ya mungkin hanya saya dengarkan saja. (Wcr85H39) Saya menghormati diri sendiri, saya juga bangga menjadi diri saya sendiri. (Wcr94H39) Saya cenderung orangnya tidak ikut-ikutan. Seperti kayak demo panci harganya itu mahal mbak, saya waktu itu tidak ada uang, tetapi teman-teman arisan/ibu-ibu arisan semuanya pada membeli tapi saya juga tidak terkecoh. (Wcr99H39) Humm, saya mempunyai teman banyak ya mbak, mereka juga mengenali saya. Saya ya menghargai diri saya sebagaimana saya. (Wcr108H39) Masalah fisik, ya namanya orang sudah menopause ya pasti mengalami perubahan fisik. Tetapi saya pede saja dengan diri saya. Saya juga masih membeli make up seperlunya. (Wcr114H39) Saya percaya itu, tadi kan sudah saya jelaskan ya mbak ya seperti itu. Tetapi saya ada sepenggal cerita mbak. Istri dari mas saya, itu seumuran dengan saya, kami dulunya juga berteman. Tetapi mbak ipar saya ini belum menopause. Saat saya bercerita dengan mbak ipar saya, mbak ipar saya ini merasa tersinggung dengan ucapan saya. Tetapi ucapan saya itu tidak bermaksud menyinggungnya. Jadi begini saat saya bilang "mbak awak dewe iku gak mungkin berada nak dukur terus, roda iku berputar, nah awak dewe yo gaenak nek tuwek ngkuk njagakno anak, sampean saiki sek durung pegel nek dodolan panganan tapi pas nek tuwo ngkuk mosok sampean dodolan panganan trus?" jawaban mbak ipar saya "loh, Put delok. en ta tantemu Put, ngenyek Put" bilang Put itu nama anaknya. Saat itu ada anaknya, ada ponakan saya. Saya menjawab "loh ojok salah paham sek mbak, aku iki yo ndelok ke depane, aku iki mek ngandani pandangane ke depane yok opo". Saya tidak merasa terbebani atau bagaimana, saya juga tidak merasa sakit hati, saya juga saat itu menjelaskan dengan baik \& akhirnya mbak ipar saya mengerti. (Wcr123H39) Tidak mbak, saya malah ingin menjelaskan, ingin memberikan pandangan yang baik untuk mbak ipar saya. (Wcr156H40) Selama ini saya dihormati oleh orang lain, dihargai pendapat saya. Saya ada cerita begini, saat itu saya pergi ke pasar bersama dengan suami saya. Saya membeli toples untuk tempat jajan. Nah, saat saya sudah cocok dengan toples itu saya mencari suami saya dan bilang kepada penjual "sek nggeh pak" penjualnya bilang "nggeh bu" lalu saya kembali dengan suami saya ke toko tersebut dan menanyakan toples mana yang harus saya beli, kata suami saya "seng plastik ae, cek gak gampang pecah" lalu saya akhirnya membeli toples yang plastik dan membayarnya. Lalu si penjual toples bilang begini "sampean cocok dadi anggota DPR bu, wong duwit niku wonten jenengan mawon nopo'o kok kondo kale bojone panjenengan" (Wcr163H40) Tidak, saya merasa sudah cukup berhasil dalam mencapai tujuan hidup. (Wcr185H41) Saya perna merasakan ketidakstabilan hati ya saya selalu berbagi cerita dengan anak pertama saya, adek perempuan saya atau juga bisa dengan suami saya. Dengan saya curhat saya bisa berbagi suka duka kepada sesama. Dan juga terkadang mereka yang 
curhat kepada saya, begitulah. (Wcr190H41) Saya selama ini dan detik ini selalu bersyukur kepada Maha Kuasa. (Wcr200H41) Saat saya berumur 17 tahun. Saya terlambat mendapatkan haid pertama. Kata dokter saat saya sedang memeriksakan diri ke dokter mengatakan kalau terlambat mendapatkan haid pertama kali maka masa menopause saya lebih cepat. (Wcr204H41) Iya mbak saya hanya sebagai ibu rumah tangga, disaat kosong saya suka dengan pekerjaan merajut atau membantu suami saya. (Wcr214H41) Saya hanya mempunyai 2 anak, anak 1 saya perempuan, anak ke 2 saya laki-laki. (Wcr220H41) Saya tidak merokok mbak, suami saya juga tidak merokok. (Wcr225H42) Pada umur 46 tahun saya sudah mengalami menopause. (Wcr229H42) Dulu menggunakan suntik KB mbak, tapi sekarang sudah saya lepas semenjak saya sudah menopause. (Wcr233H42)

Hasil obervasi atau pengamatan peneliti pada kondisi lingkungan rumah subjek didapatkan data sebagaimana berikut:

Hasil pengamatan peneliti lingkungan subjek letak rumahnya berada di gang nomer 2 dari pojok dan nomor rumahnya juga nomer 2. Depan rumah subjek adalah rumah kosong yang belum berpenghuni. Rumah subjek berukuran $7 \times 13$, rumah telah bertembok dan pintu serta jendelanya berkayu jati. Rumah subjek berada pada ketinggian lebih dari 2000-3000m dari permukaan laut. (Obs1H43)

Dari sisi bagaimana kasus harga diri positif yang terungkap, dapat digambarkan sebagai berikut;

...Saya kan mungkin lebih tua dari suami saya, mungkin hanya berjarak beberapa bulan saja...(Wcr21H37) ... saya juga mengikuti arisan rutin sebulan 1 kali. (Wcr53H38) ....Istri dari mas saya, itu seumuran dengan saya, kami dulunya juga berteman. Tetapi mbak ipar saya ini belum menopause. Saat saya bercerita dengan mbak ipar saya, mbak ipar saya ini merasa tersinggung dengan ucapan saya.Tetapi ucapan saya itu tidak bermaksud menyinggungnya. Jadi begini saat saya bilang "mbak awak dewe iku gak mungkin berada nak dukur terus, roda iku berputar, nah awak dewe yo gaenak nek tuwek ngkuk njagakno anak, sampean saiki sek durung pegel nek dodolan panganan tapi pas nek tuwo ngkuk mosok sampean dodolan panganan trus?" jawaban mbak ipar saya "loh, Put delok.en ta tantemu Put, ngenyek Put" bilang Put itu nama anaknya. Saat itu ada anaknya, ada ponakan saya. Saya menjawab "loh ojok salah paham sek mbak, aku iki yo ndelok ke depane, aku iki mek ngandani pandangane ke depane yok opo". Saya tidak merasa terbebani atau bagaimana, saya juga tidak merasa sakit hati, saya juga saat itu menjelaskan dengan baik \& akhirnya mbak ipar saya mengerti. (Wcr123H39) ...si penjual toples bilang begini "sampean cocok dadi anggota DPR bu, wong duwit niku wonten jenengan mawon nopo'o kok kondo kale bojone panjenengan" (Wcr163H40)

Temuan lain yang dapat dijelaskan berdasarkan pada pertanyaan penelitian hasil wawancara di lapangan yang berkaitan dengan harga diri pada subjek adalah sebagai berikut:

Sebagai upaya untuk menemukan dan menggambarkan harga diri yang dialami subjek yang menopause, terdapat beberapa pertanyaan yang diajukan. Pertanyaannya 
terkait dengan kecenderungan lebih efektif, aktif, asertif, sikap menghormati dan menghargai diri sendiri dan orang lain. Berikut akan digambarkan data subjek dari hasil wawancara.

Petikan wawancara untuk subjek terkait harga diri subjek. Berikut ini petikan wawancara dari subjek sebagaimana berikut:

...buat apa juga saya merendahkan orang lain. Saya bisa nerima orang lain dengan bagaimana dia, karena kan memang sifat pribadi orang itu beda-beda mbak. (Wcr2H37) ...tapi kalau merendahkan diri sendiri itu kan merasa saya ini rendahan seperti itu, ya tidak mbak. (Wcr14H37) Saya perna mengutarakan pendapat saya,...(Wcr21H37) ...saya memiliki banyak teman, saya juga mengikuti arisan rutin sebulan 1 kali. (Wcr53H38) ... disaat kosong saya suka dengan pekerjaan merajut ...(Wcr214H41)

Sebagai upaya untuk menemukan dan menggambarkan subjek dari faktor-faktor yang mempengaruhi menopause. Terdapat beberapa pertanyaan yang diajukan. Pertanyaannya terkait dengan faktor-faktor yang mempengaruhi menopause. Berikut akan digambarkan data subjek dari hasil wawancara.

Petikan wawancara untuk subjek terkait faktor-faktor yang mempengaruhi menopause. Berikut ini petikan wawancara dari subjek sebagaimana berikut:

Saat saya berumur 17 tahun. Saya terlambat mendapatkan haid pertama. Kata dokter saat saya sedang memeriksakan diri ke dokter mengatakan kalau terlambat mendapatkan haid pertama kali maka masa menopause saya lebih cepat. (Wcr204H41) Iya mbak saya hanya sebagai ibu rumah tangga, disaat kosong saya suka dengan pekerjaan merajut atau membantu suami saya. (Wcr214H41) Saya hanya mempunyai 2 anak, anak 1 saya perempuan, anak ke 2 saya laki-laki. (Wcr220H41) Saya tidak merokok mbak, suami saya juga tidak merokok. (Wcr225H42) Pada umur 46 tahun saya sudah mengalami menopause. (Wcr229H42)

Petikan dari subjek tersebut dapat dianalisis berdasarkan tema-tema yang sudah ditentukan pada transkrip saat wawancara. Analisisnya yang diuraikan sebagai berikut, subjek memiliki harga diri yang tinggi karena subjek tidak merendahkan orang lain dan diri sendiri (Wcr2H37; Wcr14H37), menghormati orang lain dan diri sendiri (Wcr94H39; Wcr85H39), memiliki banyak teman (Wcr53H38), mengikuti kegiatankegiatan kampung (Wcr54H38), percaya diri (Wcr116H39), mendapat penerimaan diri oleh sendiri maupun orang lain (Wcr165H40), menerima kritik dan saran dengan baik (Wcr85H39), tidak mudah tersinggung (Wcr156H40), merasa sudah berhasil (Wcr185H41), dan selalu bersyukur pada Allah (Wcr200H41).

Penampilan subjek sederhana dan juga melihat situasinya seperti apa (Wcr9H37). Dalam memberikan pendapat subjek tidak malu untuk mengutarakan pendapatnya (Wcr21H37). Dalam menyikapi masalah subjek percaya bahwa semua masalah pasti dapat diselesaikan dan subjek juga percaya bahwa Allah tidak pernah memberikan cobaan diluar batas kemapuan umatnya (Wcr39H38). Subjek cenderung orangnya tidak ikut-ikutan (Wcr99H39). Subjek mengalami menstruasi pertama kali saat berumur 17 tahun, dan subjek mengaku bahwa memang beliau mengalami keterlambatan menstruasi 
yang pertama kalinya (Wcr204H41). Pekerjaan subjek hanya sebagai ibu rumah tangga, saat kosong subjek merajut atau membantu suaminya (Wcr214H41). Subjek hanya memiliki 2 orang anak (Wcr220H41). Subjek dan suaminya tidak ada yang merokok (Wcr225H42). Subjek mengalami menopause pada umur 46 tahun (Wcr229H42). Subjek dulunya menggunakan suntik KB, tetapi sekarang sudah tidak menggunakan (Wcr233H42). Rumah subjek berada pada ketinggian lebih dari 2000-3000m dari permukaan laut (Obs5H43).

Dari uraian data di atas yang ditemukan di lapangan, akan dibahas atau diinterpretasikan pada bab selanjutnya. Data-data tersebut akan di analisis berdasarkan kategori yang akan dibuat peneliti. Kategori yang dibuat untuk memudahkan pembahasan berdasarkan temuan lapangan.

Berdasarkan hasil temuan di lapangan terkait selfesteem subjek yang menopause dapat digambarkan hasil temuan berdasarkan temuan berikut ini.

Pada subjek, harga diri subjek yang positif, yaitu subjek tidak merendahkan orang lain dan diri sendiri (Wcr2H37; Wcr14H37), menghormati orang lain dan diri sendiri (Wcr94H39; Wcr85H39), memiliki banyak teman (Wcr53H38), mengikuti kegiatankegiatan kampung (Wcr54H38), percaya diri (Wcr116H39), mendapat penerimaan diri oleh sendiri maupun orang lain (Wcr165H40), menerima kritik dan saran dengan baik (Wcr85H39), tidak mudah tersinggung (Wcr156H40), merasa sudah berhasil (Wcr185H41), dan selalu bersyukur pada Allah (Wcr200H41).

Penampilan subjek sederhana dan juga melihat situasinya seperti apa (Wcr9H37). Dalam memberikan pendapat subjek tidak malu untuk mengutarakan pendapatnya (Wcr21H37). Dalam menyikapi masalah subjek percaya bahwa semua masalah pasti dapat diselesaikan dan subjek juga percaya bahwa Allah tidak pernah memberikan cobaan diluar batas kemapuan umatnya (Wcr39H38). Subjek cenderung orangnya tidak ikut-ikutan (Wcr99H39).

Dari uraian di atas dapat dikemukakan menurut (Wati, 2014) bahwa harga diri subjek positif karena subjek selalu memiliki harga diri yang tinggi dan salah satu komponen konsep diri yaitu harga diri dimana harga diri adalah penilaian individu tentang pencapaian diri dengan menganalisa seberapa jauh perilaku sesuai dengan ideal diri.

Pada subjek juga ditemukan faktor-faktor yang mempengaruhi menopause, yaitu subjek mengalami menstruasi pertama kali saat berumur 17 tahun, dan subjek mengaku bahwa memang beliau mengalami keterlambatan menstruasi yang pertama kalinya (Wcr204H41). Beberapa penelitian menemukan hubungan antara umur pertama mendapat haid pertama dengan umur sewaktu memasuki menopause. Semakin muda umur sewaktu mendapat haid pertama kali, semakin tua usia memasuki menopause (Blackburn et al., 1994). Pekerjaan subjek hanya sebagai ibu rumah tangga, saat kosong subjek merajut atau membantu suaminya (Wcr214H41). Ada peneliti yang menemukan pada wanita yang tidak menikah dan bekerja, umur memasuki menopause lebih muda dibandingkan dengan wanita sebaya yang tidak bekerja dan menikah (Blackburn dan Davidson, 1990). Tetapi subjek tidak bekerja sehingga masa menopausenya juga masuk 
dalam kriteria yang normal yaitu mulai usia antara 40 sampai 50 tahun (Kartono, 1992). Subjek hanya memiliki 2 orang anak (Wcr220H41). Ada peneliti yang menemukan makin sering melahirkan, makin tua baru memasuki menopause. Kelihatannya kenyataan ini lebih sering terjadi pada golongan ekonomi berkecukupan dibandingkan pada golongan masyarakat ekonomi kurang mampu (Blackburn dan Davidson, 1990). Subjek dan suaminya tidak ada yang merokok (Wcr225H42). Wanita perokok kelihatannya akan lebih muda memasuki usia menopause dibandingkan dengan wanita yang tidak merokok. (Blackburn dan Davidson, 1990) Subjek mengalami menopause pada umur 46 tahun (Wcr229H42). Umur rata-rata wanita memasuki menopause pada umur 45 tahun sebanyak 4,3 \%dan 54 tahun sebanyak 96,4 \% sudah memasuki menopause. Sedangkan pada menopause terlalu dini ditemukan adanya penurunan fungsi kelenjar indung telur mulai umur 30-45 tahun (Blackburn dan Davidson, 1990). Subjek dulunya menggunakan suntik KB, tetapi sekarang sudah tidak menggunakan (Wcr233H42). Karena obat-obat KB memang menekan fungsi hormon dari indung telur, kelihatannya wanita yang menggunakan pil KB lebih lama baru memasuki umur menopause (Blackburn dan Davidson, 1990). Rumah subjek berada pada ketinggian lebih dari 2000-3000m dari permukaan laut (Obs5H43). Wanita yang tinggal diketinggian lebih dari 2000-3000m dari permukaan laut lebih cepat 1-2 tahun memasuki usia menopause dibandingkan dengan wanita yang tinggal diketinggian < $1000 \mathrm{~m}$ dari permukaan laut (Blackburn et al., 1994).

\section{Kesimpulan}

Kesimpulan yang dapat di hasilkan dari penelitian tentang harga diri pada wanita yang menopause yang mengungkapkan pengalaman dan yang dialaminya saat ini adalah yaitu harga diri subjek yang positif, misalnya menghargai orang lain dan tidak merendahkan orang lain, menghargai diri sendiri dan tidak merendahkan diri sendiri, mengemukakan pandangan atau pendapat terutama ketika ditanya dan melakukan rasionalisasi ketika gagal melakukan sesuatu, memiliki banyak teman dan juga mengikuti kegiatan sosialisasi dengan daerah lingkungan sekitar, meskipun tidak terlalu aktif, tetapi lebih cenderung aktif dalam menyesuaikan diri dengan tuntutan dan tekanan lingkungan, menerima keadaan saat menopause dan merasa bahagia, menerima diri dengan baik dan lebih percaya diri terhadap dirinya yang sudah memasuki masa menopause, menerima dan menghargai kritik dan saran dari orang lain terhadap dirinya, menghormati diri sendiridan bangga terhadap diri sendiri, cenderung tidak konformitas dan menerima keadaan dalam hal fisik dan materi, sikap tidak mudah tersinggung dan dapat menerima sikap orang lain dengan baik, apabila terjadi kecemasan beliau memiliki cara untuk mengatasinya dengan berbagi cerita dengan orang-orang terdekat dan selalu mensyukuri apa yang dimiliki.

Faktor-faktor yang mempengaruhi menopause, yaitu umur sewaktu mendapat haid pertama kali (menarch), jumlah anak, merokok, cuaca dan ketinggian tempat tinggal dari pemukiman laut. 
Iffah Dewi Amalya, Andik Matulessy dan Amanda Pasca Rini

Untuk peneliti selanjutnya, disarankan untuk melakukan penelitian dengan menggali lebih mendalam untuk melihat faktor-faktor lainnya yang lebih menyebabkan harga diri pada wanita yang sudah menopause menjadi positif atau negatif yang belum diungkap oleh peneliti dan menambah jumlah subjek penelitian yang mendukung harga diri pada wanita yang menopause.

\section{BIBLIOGRAFI}

Abadiah, Sa'adatul. (2016). Motivasi berafiliasi pada dewasa awal yang nongkrong di cafe. UIN Sunan Ampel Surabaya.

Bernard, Michael Edwin. (1990). Taking the stress out of teaching. Collins Dove.

Blackburn, Ivy Marie, Davidson, Kate, \& Kendell, R. E. (1994). Terapi kognitif untuk depresi dan kecemasan suatu petunjuk bagi praktisi. Alih Bahasa: Rusda Koto Sutadi. Semarang: IKIP Semarang Press.

Drobnjak, Suzana, Atsiz, Semra, Ditzen, Beate, Tuschen-Caffier, Brunna, \& Ehlert, Ulrike. (2014). Restrained eating and self-esteem in premenopausal and postmenopausal women. Journal of Eating Disorders, 2(1), 1-10. https://doi.org/10.1186/s40337-014-0023-1

Elavsky, Steriani, \& McAuley, Edward. (2007). Exercise and self-esteem in menopausal women: A randomized controlled trial involving walking and yoga. American Journal of Health Promotion, 22(2), 83-92.

Ermawati, Dwi Hesti. (2018). Menopause and Biopsychosocial Factors Associated with Quality of Life in Women in Surakarta, Central Java. Journal of Maternal and Child Health, 03(02), 119-127.

Gibson, Donna M., \& Jefferson, Renee N. (2006). The effect of perceived parental involvement and the use of growth-fostering relationships on self-concept in adolescents participating in gear up. Family Therapy, 33(1), 29.

Hidup, Wanita. (2005). Jurnal Kualitas Hidup Pada Wanita Yang Sudah Memasuki Masa Menopause.

Kartono, Kartini. (1992). Psikologi Wanita: Mengenal wanita sebagai ibu dan nenek. Bandung: Mandar Maju.

Olchowska-Kotala, Agnieszka. (2018). Body esteem and self-esteem in middle-aged women. Journal of Women and Aging, 30(5), 417-427.

Orizani, Chindy Maria. (2014). Harga Diri Pada Wanita Menopause (Menopausal Women's Self Esteem). (95), 55-58.

Runiari, Nengah, Hartati, Ni Nyoman, \& Surinati, Dewa Ayu Ketut. (2015). Citra 
Tubuh, Harga Diri dan Kepercayaan Diri dengan Kualitas Hidup Wanita Menopause. Jurnal Gema Keperawatan, 8(1), 55-63.

Séjourné, Natalène, Got, Fabrice, Solans, Catherine, \& Raynal, Patrick. (2019). Body image, satisfaction with sexual life, self-esteem, and anxiodepressive symptoms: A comparative study between premenopausal, perimenopausal, and postmenopausal women. Journal of Women and Aging, 31(1), 18-29.

Subagya, Ami Novianti, Artanty, Wenny, \& Hapsari, Elsi Dwi. (2018). Hubungan Harga Diri dengan Kualitas Hidup Wanita Menopause. Jurnal Persatuan Perawat Nasional Indonesia (JPPNI), 2(3), 177.

Wati, E. K. A. Hajar. (2014). Pengembangan Media Video Boneka Tangan dalam Pembelajaran Harga Diri Mata Pelajaran Pendidikan Kewarganegaraan Siswa Kelas 3 SDN Sumberejo 2 Pakal Surabaya. Jurnal Mahasiswa Teknologi Pendidikan, 5(2). 